\title{
The anthropology of media and the question of ethnic and religious pluralism
}

This essay discusses anthropological approaches to the study of media interacting with contexts of ethnic and religious diversity. The main argument is that not only issues of access to and exclusion from public spheres are relevant for an understanding of media and pluralism. Background assumptions and ideologies about media technologies and their functioning also require more comparative analysis, as they impact public spheres and claims to authority and authenticity that ultimately produce and shape scenarios of ethnic and religious diversity. This additional dimension of diversity in the question of media and ethnic and religious pluralism is particularly apparent in crises of political and religious mediation. The latter often result in desires to bypass established forms of political and religious mediation that are in turn often projected on new media technologies.

Key words media, pluralism, religion, ethnicity, public sphere

For quite some time anthropologists have asked how media influence ethnic and religious belonging, the formation of ethnic and religious networks and communities, and how, more generally, uses of media technology shape the relationships between people of different ethnic and religious backgrounds. Do media not profoundly shape our impressions of the ethnic and religious other? After all, trends of intensified globalisation in the last three decades appear to have brought about a global mediasustained imaginary in which such representations are produced and circulated. And can media not also appear as fearful agents of separation, purism, and ethnic and religious antagonism, as most chillingly exemplified in the 1994 radio broadcasts by Radio Télévision Libre des Mille Collines that called on Rwandans to engage in genocidal murder of their neighbours?

But the subject of media and ethnic and religious diversity has of course a fairly long genealogy. It was first taken up in the study of nationalism, beginning with the work of Karl Deutsch (1953) in the early 1950s, who initiated research on how changes in the technological and economic organisation of transport and communications were responsible for shifts from more parochial to larger-scale national identities in Europe. A more recent, and certainly the best known representative of this argument is Benedict Anderson's work on nationalism in which he claimed that the rise of print capitalism, with its creation of expanding reading publics separated through vernacular linguistic diversity, was a key element in the rise of the imagined communities of nations. 
The central concept that has emerged in debates about the relationship between uses of media and the shaping of ethnic and national forms of identification is certainly the public sphere. Originally conceived by Habermas as a secular space of face-to-face rational deliberation free from control of the courts and churches (Habermas 1989 [1962]), the concept has become much more media-centric, and has been considerably extended in recent years to also include religious networks, mobilisations and debates, which, as Peter van der Veer has argued, originally brought about the modern public sphere in, for example, Britain and India (van der Veer 2001, 2004).

Publics can be understood as modern self-organising formations that vastly transcend face-to-face interactions. They therefore necessitate uses of various media technologies as a condition of possibility for publics as self-constituting forms of address. Public spheres are domains of circulating discourse and images that shape our senses of collective and political identification and our knowledge of the elementary facts of all social and political life beyond the confines of our own radius of face-to-face interaction. Thus it is clear that the inclusions and exclusions that constitute public spheres are enormously consequential, and it is indeed on this point that most of the debates about the public sphere have centred. Beginning with the early critique by Negt and Kluge (1974) of the bourgeois bias of Habermas' account, and later followed by a range of feminist and postcolonial critics, a chorus of scholars has pointed to the fact that only white, propertied males were considered part of the public sphere in the period Habermas addressed in this seminal work (Calhoun 1992). The suspicion that public spheres contain several substantial inbuilt and inherent limits and exclusions that severely constrain full participation and representation of disadvantaged groups led to the debate around counterpublics - that is, the question of whether there is ' $a$ ' public sphere or whether there are several antagonistic ones. The question remains in how far counterpublics are really fundamentally different from and thus 'counter' to mainstream publics in the way they operate, and not just at the level of the political agendas expressed. In a critique of Nancy Fraser's argument for feminist and other subaltern counterpublics, Michael Warner argued that arbitrary closures are in fact immanent to all publics, and that oppositional counterpublics replicated most of the structures of the Habermasian public, in which participants are addressed by virtue of inhabiting particular and ultimately limited social locations (Fraser 1992; Warner 2002: 85).

A question of great importance for the study of religiously and ethnically plural societies is raised here. If there is, as Warner maintains, an inbuilt tendency for arbitrary closure in any public, which ultimately rests on a structural blindness for its own limitations and exclusions, what does this imply for a pluralist politics that has the inclusion of ethnic and religious diversity as its goal?

\section{Media technologies and the politics of pluralism}

The concern over communicative inclusion and exclusion as a leading theme in debates about the public sphere has also coloured assessments of the workings of media technology. One example is the study of modern media and Islam. Here research on new media in the Muslim world has emphasised that uses of new media technology also produce new sociocultural developments in Islamic traditions. Dale Eickelman and Jon 
Anderson, for example, claim that a new class of interpreters of Islam has emerged as a consequence of uses of new forms of media, such as the internet, which has undercut the authority of established players such as the state and the "ulema (Eickelman and Anderson 1999).

New media can open up new spheres of public participation and political mobilisation as they create new kinds of media producers and consumers. In thus overcoming previous hierarchies and forms of exclusion, they are frequently considered to have a fundamentally democratising character. Here the keyword with respect to new media is transparency, which such new media practices supposedly help to bring about (Eickelman and Salvatore 2004: 9). The question of access is thus also paramount in much recent work on media and Islam. There, much of the debate is about whether uses of particular media technologies, such as cassettes or cheaply reproduced audio and video CDs, or the internet, create new dialogic contexts or establish new forms of control and discipline over discourse (Blank 2001; Eickelman and Anderson 1999), or whether these two dimensions could not be treated as interdependent (Hirschkind 2006: 105-7).

More generally, in most scholarly debates about the public sphere and ethnic and religious diversity, the issue of media and media technologies appears as one of access and representation. Actors of different ethnic and religious backgrounds struggle for public representation and new forms of expression, which frequently also leads to the reshaping of senses of the self, or ethnicity or religious traditions, or all of them together. New or relatively new electronic media are important for this debate, because they can change the way public spheres are accessed and constituted, and because their use can redraw their boundaries of inclusion and exclusion.

However, what in my view should deserve a lot more systematic attention is the question of how such media also change what they mediate in a qualitative sense, while at the same time disappearing in the act of mediation. What does this mean for a politics of pluralism? In this essay I want to critically engage the anthropology of media in light of this question, and point to what in my view has emerged as a blind spot in analyses of public spheres and diversity. In my view, this is really the question of mediation in a stricter sense, that is the reshaping and reworking of discourse and images in a process of technological mediation. Above all, the role of the different ideologies and theologies of media and the ways they condition the politics of pluralism in modern nation states is often sidelined in approaches that treat media simply as channels of dissemination, following the common sense assumption that new media are simply more efficient and faster conduits of communication.

\section{Media anthropology}

Perhaps no other field of knowledge is as well positioned to address the question of mediation taken seriously from a comparative perspective than the anthropology of media. Beginning with the research of Terry Turner, Faye Ginsburg and others on indigenous media, and now among other topics also including a focus on religious counterpublics (Hirschkind 2006; Meyer 2006a), and media producers, such as journalists and film producers (Boyer 2005; Boyer and Hannerz 2006), anthropologists have analysed uses of new media technologies as profoundly interconnected with 
diverse cultural frames of reference. ${ }^{1}$ This has led them to a particular focus on media consumption, initially also inspired by the work of Stuart Hall in cultural studies, whose work emphasises the role of media audiences as active producers of media messages and their meanings (Hall 1980). Along these lines, anthropologists have shown how local audiences sometimes drastically transform media texts and messages by relating them to local entertainment genres and sociocultural values.

One important area of research is the appropriation of electronic media technology by indigenous or otherwise subordinate groups for 'cultural activism' (Ginsburg 1993) aiming at political empowerment (Turner 2002). Linguistic anthropologists, with their long-standing interests in the cultural contexts of literacy, have also turned their attention to the study of electronic media (Jones and Schieffelin 2009; Goebel 2008). A further focus is transnational media circuits and the ways they are shaped by cultural preferences and contexts of both producers and consumers outside the West, as in for example in recent work on the viewing of and debates about Indian films in northern Nigeria and South Africa (Larkin 1997; Hansen 2005). The production and reception of government-controlled television in postcolonial states with its agendas of nation-building, social reform and development, has emerged as another fruitful field of investigation by anthropologists, as in the work of Lila Abu-Lughod on Egypt (2005) and Purnima Mankekar on India (1999). Anthropologists have also paid attention to the mediatic dimensions of practices of governance, for example stressing how the material specificities of bureaucratic media such as files shape the politics and conflicts surrounding state institutions (Hull 2008).

Finally, there is a growing interest among anthropologists in the use of contemporary media in religious practices. Anthropologists tend to analyse media as intrinsic to religion (de Vries 2001), and ask how the use of media technology articulates with the mediation of the transcendental (Hirschkind 2006; Meyer 2006a; Oosterbaan 2008; Schulz 2006; van de Port 2006). An important issue is also the creation of new publics and forms of religious authority through the use of new media technology, such as audiovisual media in Ghana (Meyer 2006a), audiocassette sermons in Egypt (Hirschkind 2006), and televangelism in the Americas (Birman 2006). Anthropologists pay attention to the 'remediation' or reframing of already established media that authenticate religious experience and authority through new media (Meyer 2005). This line of investigation has examined the tensions between different forms of mediation in contemporary religious practice, such as scripture versus the attractions of audiovisual media or electronic sound reproduction. In contrast to most media theorists' approaches, they have analysed such contested 'remediations' of older media by new ones (Bolter and Grusin 1999), not in terms of the media technologies' supposed intrinsic qualities, but above all with an eye to how each of these media has become part of a particular cultural setting.

\section{Dialectics of mediation and immediacy}

Following this overview, one might conclude that not only in the field of anthropology,

1 The anthropology of media as an identifiable field of study only dates back to the late 1980s. However, there were some anthropological engagements with media practices before, perhaps the earliest and most notable being Hortense Powdermaker's study of the Hollywood film industry (Powdermaker 1950).

(C) 2011 European Association of Social Anthropologists. 
but also in much of the social sciences and the humanities, many of today's central research questions can be recast as media questions. And in fact, media and uses of media have been credited with extraordinary powers in not just shaping and mediating, but even producing many of the social and political processes, formations and institutions that anthropologists are grappling with today. Media and media practices are widely held to create or co-create new subjectivities and identities, the nation, the public sphere, globalisation, the so-called 'revival' of religion, as well as transnational connections and flows of different kinds. As Charles Hirschkind and Brian Larkin have put it recently, 'media takes on the power of religion to both destroy and remake individual sensibilities and create anew the grounds for communal belonging' (2008: 3). It is probably no exaggeration to say that a particular form of media constructionism and media generativism has become a position of consensus in much of anthropology.

This widespread perspective, however, raises a major problem. On one hand, the role of media as creators and as generators of new cultural forms and processes is obvious and remains the main focus of anthropological studies of media. On the other hand, there is also a frequently observed phenomenological quality of media that seems to contradict media constructionism and generativism. This is the tendency of media to disappear in the act of mediation. In fact, media can only function as such if in the act of conveying something they are also capable of drawing attention away from their own materiality and technicality in order to redirect attention to what is being mediated. This capability of media to at least momentarily 'stand back' and withdraw from perception seems to be the very condition of their functioning, and is indeed central to the definition of what constitutes a medium (Krämer 2008). An early insight in this problematic can be found in Aristotle's discussion of media diaphana or transparent media, such as in the example of air as a medium of perception that only becomes an object of perception itself if it ceases to function in the expected way, such as in blurring our vision or disabling hearing (Hoffmann 2002: 30-5). Whether in the act of consuming audiovisual media, making a phone call, watching a movie, being immersed in a book, or working on a computer watching its screen, as long as these media appear to be operating properly, for their habitual users they recede in the background, to the point of vanishing almost entirely in the face of what they mediate. That is, in successful acts of mediation what is being mediated appears to be fully and solely present, while the mediating apparatus with the social relations and institutions it is embedded in withdraws into absence. Nonetheless, according to a large and ever growing body of literature, the withdrawing and disappearing medium paradoxically accounts for the very creation and production of political and cultural processes and institutions. One theoretical question raised here is thus how to relate the multiple findings about the creative power of media practices to this key phenomenological characteristic of media, which is their propensity to erase themselves in the act of mediation. How can this 'disappearing' phenomenological quality of media be reconciled with their creative and generative roles that anthropologists so frequently comment on?

Media, of course, do not seem to be working seamlessly all the time and are not always perceived as transparent. In a range of historical and cultural contexts there have been recurring instances of dissatisfaction with established forms of media, resulting in the search for new media affording seemingly more 'direct' and 'immediate' relationships to others, political and religious institutions, or God. Sometimes such desires have even aimed at a millenarian, utopian removal of mediation altogether, 
striving for unsullied, immediate unity with others, the supreme political good, or supernatural forces.

Another way to put this is that the potential for the medium to disappear pertains to the ordinary, everyday functioning of mediation, but also facilitates the denial of mediation altogether. In anthropological writings, recently discussed examples for such striving for more immediate links to others or to supernatural actors include Protestantism in general, contemporary Evangelism in particular, as well as the hopes placed on so-called 'e-governance'. The effect of relatively unmediated transparence is inherent in any properly functioning medium, but what are the conditions that make desires for such transparence particularly salient? One question posed here is in what particular circumstances desires for the bypassing, or even denial, of mediation become acute and pressing.

One answer, I suggest, is to be found in the numerous instances in which a 'politics of immediation', to use William Mazzarella's phrase, turns out to be a strategy of power and authority (Mazzarella 2006). That is, a denial of mediation and the accompanying illusion of pure immediate access to political and spiritual sources, personalities and centres mobilise a capacity inherent in media for political effect. This illusion of immediate and transparent access in turn accounts for the power of media to bring about political mobilisation, and to rally and shape ethnic and religious identities, while at the same time denying and dissimulating its profoundly political character.

Thus, there is more to the drive towards direct connection and the overcoming of previous institutional or spatiotemporal barriers through new media technologies than its obvious capitalist dimensions. David Harvey, further analysing a scenario already anticipated by Marx, has described what he called the process of 'timespace compression' inherent in capitalism, a mobilisation of new transport and communication technologies aiming at a vanishing point of simultaneity and the elimination of distances to maximise economic turnover and surplus, from steamships to the internet (Harvey 1989). It would be foolish to ignore this crucial dimension of media technologies, but the point is that desires for directness and immediacy through such new technologies can also be traced to the power and authorisation that actors derive from claiming a more immediate link to desired political or religious destinations or moral goods. And this dynamic, which ultimately rests on the phenomenological and aesthetic qualities of media, cannot be derived from the workings of global capitalism.

One prominent example is the use of modern media technology in religion. In the contemporary world followers of the most diverse religious traditions have adopted the use of modern media technologies such as audiovisual technologies and sound reproduction in their religious practices. Scholars have demonstrated how such contemporary media uses in the field of religion connect to processes of imagining national and religious communities, and the dynamics of transnationalism and globalisation, and have provided important insights into how religious media become part of public spheres in which they blend with the realms of consumption, advertisement and entertainment. Religion and religious pluralism is also of key importance for the study of ethnicity and ethnic conflict, precisely because religion cannot be reduced to its often-observed function as an ethnic marker. This is because religion also often provides resources for the moral arrangements and underpinnings of ethnic pluralism, which especially in the contemporary world is inseparable from the circulation of various forms of religious media (Eisenlohr 2006c). 
But the dynamics of media understood in a stricter sense can also drive conflict and contestation in religiously plural settings. In the present-day world perhaps the most important of these dynamics is that religious practitioners often recast older claims for a more direct or 'immediate' access to supernatural forces through their deployment of contemporary media technologies, which may go hand in hand with radicalisation or maximisation of religious claims in social and political worlds. While from a philosophical and theological point of view the deployment of ever more complex human artefacts in pursuit of immediacy in interacting with the divine constitutes an intriguing paradox, empirical studies of media use have shown that claims for a more direct, unmediated access to the supernatural, however conceived, are also part of strategies of power (Engelke 2007; Meyer 2006a; Keane 2007). That is, they bolster claims of moral superiority that frequently also involve claims to authority in other social and political fields. The sources of conflict in which religion and religious difference plays a major role can thus at least partly be located in the religious processes of mediated interaction themselves, and they appear to be integral to the reproduction and transformation of religious traditions.

The recent history of the Hindu nationalist movement in India provides a good illustration of how uses of modern media technology qualitatively change politics of religious diversity and mobilisation. The enormously popular televised broadcasting of the TV adaptation of the Ramayana epos in 78 episodes by the state-controlled Doordarshan network in the late 1980 s is widely credited with preparing the ground for the political rise and bid for power of Hindu nationalists in India shortly after. Reactions to the serial among Indian television viewers were actually quite diverse, split along the lines of class, caste, gender and religious background, as for example documented by Purnima Mankekar in her ethnography of television and nationhood in India (1999). This point is very much in the spirit of most anthropological studies of media today, which almost always reject the claim that well-crafted media messages can decisively shape and determine an audience's reaction and override their critical faculties, as they point to the viewers' agency, and the diversity and local socio-cultural embeddedness of media consumption instead.

We could of course continue to add studies that make this a final point. But even if all reception is local and diverse, the question remains what precisely accounts for the obvious powers of modern audiovisual media to greatly mobilise and normalise, at least for a time, and on certain issues, the views of much of its audience? Many claim this was actually the case with the broadcasting of the Ramayana. I suggest that this problem actually remains a key question in the study of media and ethnic and religious diversity. And I think the answer to this question can only be found by paying more sustained attention to some of the formal characteristics of media technologies and media genres, as they become embedded in particular cultural and historical contexts.

This may also include other forms of media already present. As Arvind Rajagopal has pointed out, the makers of the Ramayana serial made skilful use of the technical possibilities of television, and blended them with both the aesthetics of traditional live Ramlila performances of the epic, and longstanding generic conventions of the Hindi film industry. Above all the very frequent use of long close-up facial shots underlined with melodramatic music 'suggested the visual capture of emotions, and the extraordinary bhavna, the feeling of each act' (Rajagopal 2001: 100). This technique conveyed the highly idealised behaviour of the often divine protagonists of the epos. It used the small screen to involve the viewer in a more immediate and emotionally intense 
way with the goal to create the tightly kit moral community among its audience that would very soon turn into the political platform for Hindu nationalism. In addition, the soap opera serial format that was adopted by the producers of the televised Ramayana further promoted the sense of intimacy across social boundaries (Lefort 1986; Rajagopal 2001: 5) that was instrumental in producing the closely integrated moral community of Hindutva political ideology. It did so by insinuating itself into the rhythms of everyday life of its viewers, who came to include the broadcasting schedule into their everyday planning and routines, and turned viewing into a regular social activity with its sidespins and local metacommentary.

\section{Media, immediacy and transnational connections}

In my own research on Islam and sound reproduction technologies in Mauritius, I have also noted the importance of a media-driven politics of immediacy in struggles over transnational and diasporic authority, admittedly in a more benign scenario than the politics of Hindutva in India. Mauritian cultural politics privilege the performance of cultural, above all religious traditions marked as originating elsewhere as 'ancestral' traditions of the different ethno-religious communities distinguished by the Mauritian constitution and the Mauritian public at large. Since this politics is a prime means of inclusion in the Mauritian nation, thus representing a performance of cultural citizenship, it has also heightened concerns about the authenticity of such ancestral religious traditions. Thus, the question of who stands for authentic Islam is not only an issue of transnational authentication, and doctrinal debate, but also a very local political issue.

While studying the performance of devotional genres in honour of the Prophet Muhammad among Mauritian Muslims, I found that electronic sound reproduction technologies have come to take a large role in not only determining the authenticity of the poetry. They are also credited with enhancing the particular style of performance which is of key importance in summoning the spiritual presence of the Prophet that is sought in reciting this poetry strongly influenced by Sufi traditions of Islam (Eisenlohr 2006b, 2009). The uses of sound reproduction technologies I have documented among Mauritian Muslims depend on the assumption that this electronic media technology represents what historian of media Jonathan Sterne (2003) has called a 'vanishing mediator', a medium that erases its own traces and interferences, enabling both a maximally transparent connection to centres of Islamic authority outside Mauritius and a sense of intimacy with the Prophet.

Viewed from the outside, the performance of this particular genre of devotional poetry might seem a rather esoteric detail in Islamic practice, if it had not come to stand for a whole range of disputes in South Asian Islam, a point of crystallisation of doctrinal differences between more purist reformists and those that seek to blend 'ulema-based Islam with Sufi traditions. ${ }^{2}$ In the contemporary South Asian world, including its numerous diasporas, such differences are also shaped by media-sustained networks, in which particular forms and practices of Islam are authenticated through media use. In Mauritius, the consequences are not only a reproduction of local ethnic and religious boundaries, but also of internal debate and conflict about who represents

2 On these larger doctrinal differences in South Asian Islam see Metcalf (1982) and Sanyal (1996).

(C) 2011 European Association of Social Anthropologists. 
authentic Islam as the authorised 'ancestral culture' of Mauritian Muslims. What is at issue here is a tracing of channels of religious authority and authenticity through media networks. But accounting for their effects in a politics of pluralism requires not only noting that such media channels or networks are established, or examining what flows through them, but also an analysis of how they are embedded in the politics of religious authority and how those engaged in such media practices are persuaded, in other words the qualitative dimension of the mediation of discourse and images through contemporary audiovisual and digital technologies.

The Mauritian national cultural policy of privileging diasporic and so-called ancestral traditions also raises another important dimension of shaping ethnic and religious pluralism through media practices. Politics of diaspora are above all concerned with authenticating certain cultural forms and practices through minimising the temporal and spatial remove that separates the diaspora from a place identified as the faraway ancestral homeland. For example, linguistic ideologies, especially the designation and intense cultivation of certain languages as ancestral, and their subsequent use in ritual settings can bring about such a minimisation or even momentary suspension (Eisenlohr 2006a). Above all the use of Hindi in Hindu ritual contexts brings about such a momentary realigning and bridging of qualitative, as well as temporal and spatial, gaps. The main annual Shivratri pilgrimage in which a third of the island's population of 1.2 million participates, and whose destination in the uplands of Mauritius is a reconstructed sacred geography of temples and hills around a mountain lake known as Ganga Talao whose waters were consecrated with Ganges water flown in by the Indian government, is a good example. Going on this pilgrimage and performing ritual practices in the 'language of the ancestors' results in such effects of relative co-presence with the world of Indian ancestors. Here the linguistic ideology of Hindi as ancestral language together with its practical and performative dimensions appears to be functioning as a medium between the diasporic homeland and Hindu Mauritians, while having particular effects on the local politics of pluralism.

One could of course in good anthropological fashion deconstruct this ideology as a mere invention and rather contingent construction, beginning with the fact that modern standard (shuddh) sanskritised Hindi was actually never used by the ancestors of those Hindu Mauritians claiming it to be their ancestral language. But this would be to miss the larger point that the processes mediating between assumed diasporic origin and diaspora are crucial in the authenticating force they provide. Particular language ideologies bring about a naturalised and immediate link between people and desired political or religious goods and values. In my case here these include not only living up to heroic ancestral ideals but actually being one with the ancestors.

My point here is that media, or better put, particular ideas and background assumptions about media can accomplish something very similar. In seeming to withdraw in the face of what is being mediated, media can create commensurabilities across wide spatiotemporal and qualitative gaps to the point that their uses can produce similar experiences of relative immediacy of a diasporic origin in the ancestral land. Such media uses then move Mauritians to a particular politics of ancestral culture with its distinct effects on Mauritian ethnic pluralism, in particular the exclusion of Creoles, an ethnic group largely descended from African slaves whose experience of slavery and subsequent socio-economic exclusion has made them unable to reconstruct and institutionalise recognised ancestral traditions on a par with Indo-Mauritians. While the suspension of time and space seemingly effected by modern media technologies 
may at first appear politically innocent, the relatively immediate experience of images and discourse from another place recognised as ancestral may ultimately have the effect of empowering a purist politics of diaspora with exclusionary character, which in the case of the Hindu majority of Mauritius favours a politics in which Hindu nationalists are key actors.

This latter point links up research on media under conditions of ethnic and religious pluralism with the study of transnationalism and globalisation more generally. Uses of modern media technology in pursuit of immediate experiences of the spiritual or of faraway places and times interact with and respond to the uncertainties of diasporic experience, migration and globalisation. Media practices shape visions of imagined lives, places and futures on a global scale, as they create a global imagination as a screen of projection for comparisons, with people you want to resemble and to be compared with, and those you don't want to be like (Appadurai 2006). As Arjun Appadurai has pointed out, the aspirations and uncertainties emerging from these favourable and unfavourable comparisons link the adoption of the latest media technologies with desires for certainty and purity. According to Appadurai, these wishes for purity and more favourable selfrepresentation on a global scale often turn into rage and hatred against ethnic and religious minorities, now perceived in Mary Douglas' terms as 'matter out of place'. If as several scholars have argued, present-day processes of cultural and economic globalisation are to a large degree media-driven, the use of the latest electronic media in the pursuit for purity and certainty in processes of self-fashioning on a global stage not only responds to the anxieties provoked by these developments, but at the same time further intensifies these processes.

\section{Crises of mediation and media ideologies}

At the beginning of my essay I noted that representation and participation in public spheres are key issues in assessing the consequences of modern media use for the politics of ethnic or religious pluralism. Following the discussion of how wishes for more direct or immediate experiences across spatiotemporal and qualitative gaps often become projected on modern electronic media technologies, we can now add another central issue to the discussion, the theme of crisis. One conclusion that seems to emerge from anthropological and historical studies of media is that desires for more immediate relationships with the spiritual, or political and moral values and goods, become especially acute when the established forms of connecting to them are in a crisis. German media scholar Hartmut Winkler, for example, has developed a theory of media according to which new advances in media technologies actually emerge as the material crystallisation of such epistemic and political crises (Winkler 1997, 2004). When institutions such as states or established religious institutions that mediate the relationship between people and the realm of such moral and political aspirations and ideals are viewed as failing, the wishes to bypass them may become associated with new and seemingly more efficient forms of media and media technology.

Luther's call for sola scriptura, circumventing the Roman Catholic Church as the established apparatus of mediation between the faithful and God, then seen as increasingly dysfunctional and corrupt, propelled the Protestant emphasis on translating the Bible into vernacular languages and circulating this means of a seemingly more immediate access to God through the new technology of print among a steadily 
growing reading public. In contemporary anthropological work on media it is often the postcolonial state that is supposed to mediate between citizens and the common good, which is increasingly seen as dysfunctional and corrupt by its own citizens, hence the high hopes placed on new digital technologies to bring about not only more efficiency, but above all unmediated transparency in dealing with governments and state institutions.

Not infrequently these hopes connected to new media technologies have strong religious overtones, such as in Pentecostal hopes for the global expansion of the Holy Spirit, which many Pentecostal Christians also seek to literally bring about through integrating new audiovisual media in their religious practices and services, as analysed by Birgit Meyer for Ghana (Meyer 2006a) and Rafael Sánchez for Venezuela (Sánchez 2008). And to return to the example of the televised Ramayana epos in the context of the rise of Hindu nationalism in India, the stunning success of the serial and the deep impact it had on the Indian public has been read as a response to the deep crisis of Indian secularism and the model of postcolonial state-led development connected to it (Rajagopal 2001). Here also, the issue seems to be one of overcoming established institutions mediating between citizens and desired goods and goals, such as prosperity, development, intercommunal peace and harmony, and a sense of communal empowerment. Since the postcolonial Indian state was largely seen as failing in its role of mediator of these supreme political goods, an alternative vision of a tightly knit moral community emerged. Centred on a vision of Ram rajya, the perfectly just rule of the Hindu deity Ram, already proposed as a harmonious political ideal by Gandhi, but now given a strong Hindu nationalist bent, this political and moral alternative to the postcolonial Indian state appeared to weave itself into the intimacy of everyday life with its full affective and melodramatic loading through the relative immediacy of the televised soap opera format.

One question arising from this theme of crisis is to ask what consequences the strong desires for a more direct connection to the common good provoked by the perceived weakness or corruption of established political and religious institutions have for politics of pluralism. Most of the examples I have so far mentioned do not give much reason to be optimistic, as they often result in rather purist or totalising political visions.

Indeed, in Europe there have been several experiences with politics of immediation in which the latter has had a tendency to support policies maximally damaging to pluralism. More recently, the Nazi state and also the East German communist state both pursued policies that fostered the impression that an inward popular spirit is channelled into a more perfect social and political order without, so that both are identical, not requiring any sense of mediation (Boyer 2005: 11-12). It is no coincidence that especially the Nazis were pioneers of the political uses of the latest media technologies at the time, prompting Walter Benjamin to his well-known diagnosis of the aestheticisation of politics and its dangers (Benjamin 1968). Here, expert uses of the then new radio, cinema and emerging television technologies were above all geared towards to the paradoxical denial of mediation through the use of complex media technologies. In fostering affective intensity and a sense of direct intimacy among its audiences, Nazi uses of what were then the latest media technologies sought to bring about the sense that the true, deep and authentic spirit of the German people and the Nazi state were actually one and the same, and that the inner will and aspirations of every German were now simply directly manifest in the new Nazi order. Probably the supreme example of skilful Nazi media propaganda playing on the theme of absolute unity of the German people and 
the Nazi state is Leni Riefenstahl's 'Triumph of the Will', the popular propaganda film about the 1934 Reichsparteitag at Nürnberg (Riefenstahl 1935). A corresponding sense of release and joyful awe was carefully orchestrated in these mass-mediated spectacles of Nazi power, a sense of organic oneness to which the still current German expression of somebody having an 'inner Reichsparteitag' when undergoing a profoundly satisfying and vindicating experience testifies.

But the link between perceived crisis of established political and religious institutions, high hopes placed on new media technologies to overcome such crises, and policies damaging to ethnic or religious pluralism, while clearly present, should not be over-generalised. At times, media-driven politics of immediacy in situations of crisis may also be the 'weapon of the weak' and marginalised. As Lori Allen (2009) has recently pointed out, Palestinians increasingly use the immediate directness of drastic images of human suffering to represent themselves to each other and to an international public. This instance of a politics of immediacy is certainly also the outcome of a situation of profound crisis, the Palestinian's lack of a state and political self-determination and of the rights and protection that come along with them in the global political system. Not having any effective political institutions that could mediate between them and desired political goods, in today's world of public spheres connected through transnational audiovisual media they thus appeal in an affect-laden way to the sheer, naked humanity of people under oppression and occupation. Human rights activists now also increasingly deploy comparable media strategies worldwide. Here the appeal to immediacy through mass-circulated images of human suffering may not exclusively turn into a totalising politics of purism, even though the potential for it is also there, but may also serve as advocacy for the marginalised and excluded.

I would like to add a second note of caution before one embarks on a generalised approach that treats the widespread desires for more direct or immediate connection with political and moral values and goods, or a religious otherworld, as a political stress symptom with an inbuilt tendency for purist and totalising politics. A sense of crisis of established mediating institutions and practices may not only depend on the actual social, economic and political difficulties and disruptions experienced by people. The extent to which such mediating institutions and practices are really blamed for such negative experiences can also rest on certain ideas and background assumptions about media and mediation positing an inner-outer dichotomy, according to which a higher ranked and more authentic inner self, inner spirit or essential core is problematically constrained and limited by an institutional apparatus external to it (Boyer 2005, 2007). As Webb Keane's work on the colonial and postcolonial encounters of Protestant proselytising in Indonesia suggests (Keane 2007), such assumptions are particularly characteristic of Protestantism, and cannot be adopted as a universal approach.

But because of their more generally modern character, such ideas about media and mediation are now globally relevant. As Charles Taylor has shown, modern conceptions of the self are fundamentally based on the idea of the self as a repository of inwardness, a true core of interior sentiments, ideas and dispositions that need to be authentically expressed (Taylor 1989), and that consequently can also be grievously suppressed, or distorted by an institutional apparatus external to it. Anthropologists know very well that such senses of the self resting on dichotomies of authentic interiority and external surface are not at all universal across the cultural and historical range of human experience, where the very distinction between interiority and surface is frequently absent. 
Nevertheless, similar ideologies of media can be found in a wide range of other contexts. They also include, as I for example found in my own research, uses of sound reproduction in performances of devotional poetry in honour of the Prophet Muhammad in Mauritius, which are profoundly shaped by a Sufi ontology based on a hierarchical inner-outer dichotomy of spiritual progress and attainment. But they would contrast markedly with most Hindu engagements with the divine image known as darshan, the intense and sacred experience of seeing and being seen by a deity (Eck 1998), where there is little that is problematically exterior or potentially alienating about the materialised divine image that mediates between deity and devotee (Pinney 2001). That is, in those cultural and historical contexts where there is no presupposed opposition between inner values and external mediating apparatus, such crises of mediating institutions may be greatly attenuated, or even absent.

What becomes apparent here is that there is an entire dimension of diversity in the question of media and religious and ethnic pluralism that is enormously consequential, but has so far not received much attention among those assessing the impact of media practices on the politics of ethnic and religious pluralism. This dimension of diversity of different underlying ideas of how media function may not necessarily align itself with established ethnic and religious boundaries. It is, however, indispensible to understanding the central role that uses of media play in shaping and transforming ethnic and religious diversity, and I would identify its analysis as a key challenge for not only anthropologists, but also other scholars who are interested in the study of ethnic and religious pluralism.

\section{Conclusion}

The role of media for ethnic and religious pluralism cannot be reduced to the representation of people and groups claiming certain ethnic or religious identities, or having such identities made for them by others. Nor is it exhausted by the corresponding modes of access to and exclusion from publics where discourse and images circulate. Even more consequential may be the modalities in which different ideologies and theologies of media shape the politics of pluralism in a broader sense. As uses of media technologies become imbedded in different cultural and historical contexts, the promises and dangers associated with them change, they become subject to different ideas and expectations with respect to their functioning. To put it differently, while the formal aspects of media technologies are the same or similar in a global context, ideas and expectations with respect to what media actually do vary greatly.

Taking a comparative perspective on language as the medium of communication and interaction per se, linguistic anthropologists have investigated how linguistic ideologies, politically charged ideas and background assumptions about the nature of language, language difference and use, produce and bring together senses of the self, ethnic, class and gender differences and hierarchies of the most diverse kinds. ${ }^{3}$ In a related

3 The concept of linguistic ideology was developed by Michael Silverstein (1979) and later became a leading research paradigm in linguistic anthropology in the 1990s. Webb Keane's (2003) more expansive notion of semiotic ideology is indebted to this debate in linguistic anthropology, and is also relevant to the study of background assumptions and ideologies about media technology I focus on in this essay. 
way, ideas, background assumptions and aspirations about media technologies and their functioning will require more comparative analysis, as they impact public spheres and claims to authority and authenticity that ultimately produce and shape scenarios of ethnic and religious diversity. In doing so they not only encompass background assumptions about the semiotic dimensions of media, or semiotic ideologies (Keane 2003), but also the 'sensational forms' (Meyer 2006b) media use generates and authorises. While the notion of semiotic ideologies has been developed against the background of research on linguistic ideologies, it is important to realise that media not only signify, but also generate and convey experiences and sensations. Signification and sensation are closely intertwined in uses of media, and it is important to realise that both are constitutive of media ideologies and theologies. While investigating how media produce, reproduce and remake ethnic and religious diversity, we need to pay attention to how such different theologies and ontologies of media, very often connected to particular religious traditions, profoundly shape such generative work that uses of media are widely recognised to bring about.

\section{Acknowledgement}

An earlier version of this essay was delivered as an inaugural lecture at Utrecht University on 26 May 2009.

Patrick Eisenlohr

Utrecht University

Department of Cultural Anthropology

Heidelberglaan 2

PO Box 80140

3508 TC Utrecht, The Netherlands

p.eisenlobr@uu.nl

\section{References}

Abu Lughod, L. 2005. Dramas of nationhood: the politics of television in Egypt. Chicago: University of Chicago Press.

Allen, L. 2009. 'Martyr bodies in the media: human rights, aesthetics, and the politics of immediation in the Palestinian intifada', American Ethnologist 36: 161-80.

Appadurai, A. 2006. Fear of small numbers: an essay on the geography of anger. Durham: Duke University Press.

Benjamin, W. 1968. Illuminations. New York: Harcourt, Brace and World.

Birman, P. 2006. Future in the mirror: media, evangelicals, and politics in Rio de Janeiro, in B. Meyer and A. Moors (eds.), Religion, media and the public sphere, 52-72. Bloomington: Indiana University Press.

Blank, J. 2001. Mullahs on the mainframe: Islam and modernity among the Daudi Bohras. Chicago: University of Chicago Press.

Bolter, J. D. and R. Grusin 1999. Remediation: understanding new media. Cambridge, MA: MIT Press.

Boyer, D. 2005. Spirit and system: media, intellectuals and the dialectic in modern German culture. Chicago: University of Chicago Press.

Boyer, D. 2007. Understanding media: a popular philosophy. Chicago: Prickly Paradigm Press.

Boyer, D. and U. Hannerz 2006. 'Introduction: worlds of journalism', Ethnography 7: 5-17. 
Calhoun, C. (ed.) 1992. Habermas and the public sphere. Cambridge, MA: MIT Press.

Deutsch, K. W. 1953. Nationalism and social communication: an inquiry into the foundations of nationality. Cambridge, MA: MIT Press/New York: Wiley.

de Vries, H. 2001. In media res: global religion, public spheres, and the task of contemporary comparative religious studies, in H. de Vries and S. Weber (eds.), Religion and media, 3-42. Stanford: Stanford University Press.

Eck, D. 1998. Darśan: seeing the divine image in India, 3rd edn. New York: Columbia University Press.

Eickelman, D. F. and J. W. Anderson (eds.) 1999. New media in the Muslim world: the emerging public sphere. Bloomington: Indiana University Press.

Eickelman, D. F. and A. Salvatore 2004. Muslim publics, in A. Salvatore and D. F. Eickelman (eds.), Public Islam and the common good, 1-27. Leiden: Brill.

Eisenlohr, P. 2006a. Little India: diaspora, time, and ethnolinguistic belonging in Hindu Mauritius. Berkeley: University of California Press.

Eisenlohr, P. 2006b. 'As Makkah is sweet and beloved, so is Madina: Islam, devotional genres and electronic mediation in Mauritius', American Ethnologist 33: 230-45.

Eisenlohr, P. 2006c. 'The politics of diaspora and the morality of secularism: Muslim identities and Islamic authority in Mauritius', Journal of the Royal Anthropological Institute (N.S.) 12: 395-412.

Eisenlohr, P. 2009. 'Technologies of the spirit: devotional Islam, sound reproduction, and the dialectics of mediation and immediacy in Mauritius', Antbropological Theory 9: 273-96.

Engelke, M. 2007. A problem of presence: beyond scripture in an African church. Berkeley: University of California Press.

Fraser, N. 1992. Rethinking the public sphere: a contribution to the critique of actually existing democracy, in C. Calhoun (ed.), Habermas and the public sphere, 109-42. Cambridge, MA: MIT Press.

Ginsburg, F. 1993. 'Aborginal media and the Australian imaginary', Public Culture 5: 557-78.

Goebel, Z. 2008. 'Enregistering, authorizing, and denaturalizing identity in Indonesia', Journal of Linguistic Anthropology 18: 46-61.

Habermas, J. 1989 [1962]. The structural transformation of the public sphere: an inquiry into a category of bourgeois society. Cambridge, MA: MIT Press.

Hall, S. 1980. Encoding/decoding, in S. Hall, D. Hobson, A. Lowe and P. Willis (eds.), Culture, media, language, 129-38. London: Hutchinson.

Hansen, T. B. 2005. In search of the diasporic self: Bollywood in South Africa, in R. Kaur and A. J. Sinha (eds.), Popular Indian cinema through a transnational lens, 239-60. New Delhi: Sage.

Harvey, D. 1989. The condition of postmodernity: an inquiry into the origins of cultural change. New York: Blackwell.

Hirschkind, C. 2006. The ethical soundscape: cassette sermons and Islamic counterpublics. New York: Columbia University Press.

Hirschkind, C. and B. Larkin 2008. 'Introduction. Media and the political forms of religion', Social Text 96 26: 1-9.

Hoffmann, S. 2002. Geschichte des Medienbegriffs. Hamburg: Felix Meiner.

Hull, M. 2008. 'Ruled by records: the expropriation of land and the misappropriation of lists in Islamabad', American Ethnologist 35: 501-18.

Jones, G. and B. Schieffelin 2009. 'Enquoting voices, accomplishing talk: uses of be + like in instant messaging', Language E Communication 29: 77-113.

Keane, W. 2003. 'Semiotics and the social analysis of material things', Language E Communication 23: 409-25.

Keane, W. 2007. Christian moderns: freedom and fetish in the mission encounter. Berkeley: University of California Press.

Krämer, S. 2008. Medien, Bote, Übertragung. Kleine Metaphysik der Medialität. Frankfurt: Suhrkamp.

Larkin, B. 1997. 'Indian films and Nigerian lovers: media and the creation of parallel modernities', Africa 67: 406-39.

Lefort, C. 1986. The political forms of modern society: bureaucracy, democracy, totalitarianism, J. B. Thompson (ed.). Cambridge, MA: MIT Press. 
Mankekar, P. 1999. Screening culture, viewing politics: an ethnography of television, womanhood, and nation in postcolonial India. Durham: Duke University Press.

Mazzarella, W. 2006. 'Internet X-ray: e-governance, transparency, and the politics of immediation in India', Public Culture 18: 473-505.

Metcalf, B. D. 1982. Islamic revival in British India: Deoband 1860-1900. Princeton: Princeton University Press.

Meyer, B. 2005. 'Religious remediations: Pentecostal views in Ghanaian video-movies', Postscripts 1.2/1.3: 155-81.

Meyer, B. 2006a. 'Religious revelation, secrecy, and the limits of visual representation', Anthropological Theory 6: 431-53.

Meyer, B. 2006b. Sensational forms: why media, aesthetics, and power matter in the study of contemporary religion, in H. de Vries (ed.), Religion: beyond a concept, 704-23. New York: Fordham University Press.

Negt, O. and A. Kluge 1974. Öffentlichkeit und Erfahrung. Zur Organisationsanalyse von bürgerlicher und proletarischer Öffentlichkeit. Frankfurt: Suhrkamp.

Oosterbaan, M. 2008. 'Spiritual attunement: Pentecostal radio in the soundscape of a favela in Rio de Janeiro', Social Text 96 26: 123-45.

Pinney, C. 2001. Piercing the skin of the idol, in C. Pinney and N. Thomas (eds.), Beyond aesthetics: art and the technologies of enchantment, 157-80. Oxford: Berg.

Powdermaker, H. 1950. Hollywood, the dream factory. Boston: Little and Brown.

Rajagopal, A. 2001. Politics after television: Hindu nationalism and the reshaping of the public in India. Cambridge: Cambridge University Press.

Riefenstahl, L. 1935. Triumph des Willens (Film). Berlin: Universum Film AG.

Sánchez, R. 2008. 'Seized by the spirit: the mystical foundation of squatting among Pentecostals in Caracas (Venezuela) today', Public Culture 20: 267-305.

Sanyal, U. 1996. Devotional Islam and politics in British India: Ahmad Riza Khan Barelwi and his movement (1870-1920). Oxford: Oxford University Press.

Schulz, D. E. 2006. 'Promises of (im)mediate salvation: Islam, broadcast media, and the remaking of religious experience in Mali', American Ethnologist 33: 210-29.

Silverstein, M. 1979. Language structure and linguistic ideology, in P. R. Clyne, W. F. Hanks and C. L. Hofbauer (eds.), The elements: a parasession on linguistic units and levels, 193-247. Chicago: Chicago Linguistic Society.

Sterne, J. 2003. The audible past: cultural origins of sound reproduction. Durham: Duke University Press.

Taylor, C. 1989. Sources of the self: the making of modern identity. Cambridge: Cambridge University Press.

Turner, T. 2002. Representation, politics, and cultural imagination in indigenous video: general points and Kayapo examples, in F. D. Ginsburg, L. Abu-Lughod and B. Larkin (eds.), Media worlds: anthropology on new terrain, 75-89. Berkeley: University of California Press.

van de Port, M. 2006. "Visualizing the sacred: video technology, "televisual" style, and the religious imagination in Bahian candomblé, American Ethnologist 33: 444-61.

Van Der Veer, P. 2001. Imperial encounters: religion and modernity in India and Britain. Princeton: Princeton University Press.

Van Der Veer, P. 2004. Secrecy and publicity in the South Asian public arena, in A. Salvatore and D. F. Eickelman (eds.), Public Islam and the common good, 29-52. Leiden: Brill.

Warner, M. 2002. 'Publics and counterpublics', Public Culture 14: 49-90.

Winkler, H. 1997. Docuverse. Zur Medientheorie der Computer. München: Boer.

Winkler, H. 2004. Diskursökonomie. Versuch über die innere Ökonomie der Medien. Frankfurt: Suhrkamp. 